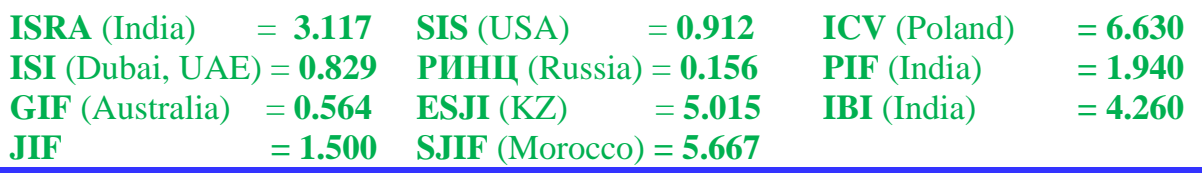

SOI: $\underline{1.1 / \text { TAS }}$ DOI: $\underline{10.15863 / \text { TAS }}$

International Scientific Journal Theoretical \& Applied Science

p-ISSN: 2308-4944 (print) e-ISSN: 2409-0085 (online)

Year: 2018 Issue: 12 Volume: 68

Published: $23.12 .2018 \quad$ http://T-Science.org
QR - Issue

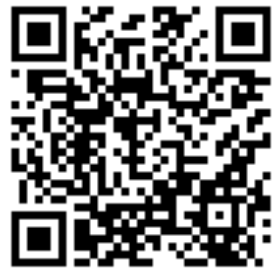

QR - Article

Otabek Mukhamadovich Fayzulloyev doctoral student of the Department of English linguistics Bukhara state University (+99891) 410-59-03 otabek-1977@inbox.ru

\title{
THE PECULIARITIES OF THE INTERPRETATION OF THE UZBEK FAIRY TALES
}

Abstract: The article is devoted to the peculiarities of the interpretation of the Uzbek fairy tale "Golden fish" into English, where we gave a detailed analysis of the linguoculturemes of the fairy tale. Besides we identified the causes of some unexplained linguoculturemes in a translated text of a fairy tale.

Key words: linguocultureme, interpretation, poor, most humble servant, harem, Khan, ethnographer, analysis, young fisherman.

Language: Russian

Citation: Fayzulloyev, O. M. (2018). The peculiarities of the interpretation of the Uzbek fairy tales. ISJ Theoretical \& Applied Science, 12 (68), 212-215.

Soi: http://s-o-i.org/1.1/TAS-12-68-29 Doi: crossef https://dx.doi.org/10.15863/TAS.2018.12.68.29

\section{ОБ ОСОБЕННОСТЯХ ИНТЕРПРЕТАЦИИ УЗБЕКСКИХ СКАЗОК}

Аннотация: Статья посвящена особенностям интерпретации Узбекской сказки "Золотая рыба" на английский язык, где приведён подробный анализ лингвокультурем сказки и выявлены причины неотраженных некоторых лингвокультурем в переведенном тексте сказки.

Ключевые слова: лингвокультурема, интерпретация, факир, камина гарем, Хан, этнограф, анализ, молодой рыбак.

\section{Introduction}

Язык каждого народа отличается от других остальных своей национальностью, подобно отпечаткам пальцев, проживающих людей на планете. С развитием цивилизации и глобализации мы имеем возможность ознакомит свой народ литературными ценностями, населявших нашу планету других жителей, в первую очередь, переводом художественных произведении на свой, родной узбекский язык.

\section{Materials and Methods}

Спора нет, что перевод - сложнейшая творческая деятельность, в процессе которого особое место занимает интерпретация единиц языка переводимых лингвокультурем художественного текста, которые содержать свои национальные особенности, присущие только тому или иному народу. Поэтому интерпретация некоторых словарных единиц языка требует особого внимания (Интерпретация - от лат.interpretatio истолкование, разъяснение. В гуманитарном знания интерпретация фундаментальный метод работы с текстами как знаковыми системами. Текст как форма дискурса и целостная функциональная структура открыт для множества смыслов, существующих в системе социальных коммуникаций. $\mathrm{OH}$ предстает в единстве явных и неявных, невербализованных значений, буквальных и вторичных, скрытых смыслов) [10].

Любая лингвокультурема языка имеет отношение к культуре, обычаем, обрядам и образу жизни народов. О сущности данного английский этнограф Э.Б.Тайлор пишет: From an ideal point of view, civilization may be looked upon as the general improvement of mankind by higher organization of the individual and society, to the end of promoting at once man's goodness, power and happiness [4; ст.42]. "С идеальной точки зрения на культуру можно смотреть как на общее усовершенствование человеческого рода путем высшей организации отдельного человека и целого общества с целю одновременного 


\begin{tabular}{|c|c|c|c|c|c|c|}
\hline \multirow{4}{*}{ Impact Factor: } & ISRA (India) & $=3.117$ & SIS (USA) & $=0.912$ & ICV (Poland) & $=6.630$ \\
\hline & ISI (Dubai, UAE & $=0.829$ & РИНЦ (Russia) & $=0.156$ & PIF (India) & $=1.940$ \\
\hline & GIF (Australia) & $=0.564$ & ESJI (KZ) & $=\mathbf{5 . 0 1 5}$ & IBI (India) & $=4.260$ \\
\hline & JIF & $=1.500$ & SJIF (Morocco) & $=5.667$ & & \\
\hline
\end{tabular}

содействия развитию нравственности, силы и счастья человека" [5;ст.36].

В данной статье предлагаем вашему вниманию особенности интерпретации узбекской сказки Олтин балиқ (Золотая рыба, Golden fish) на английский язык. Узбекская народная сказка "Золотая рыба" входит в ряд сказок о золотой рыбе (Сказка братьев Грим "Сказка о рыбаке и его жене, Индийская сказка "Сказка о золотой рыбке", Малазийская сказка "Три желания", Китайская сказка "Золотая рыба", Сказка А.С.Пушкина "Сказка о рыбаке и рыбке").

Сказка "Золотая рыба" переведена на английский язык Фаиной Соласко переведенный текст, которого является объектом нашего анализа. Текст узбекской сказки "Олтин балиқ" содержит более 7 лингвокультурем, что создаёт трудности интерпретации на другой язык, в данном случае, на английский.

При сравнительно - типологическом анализе данных сказок мы исходим с точки зрения передачи национальных языковых единиц, выражающих внутренние чувства и переживания героев сказки. В начале сказки дана характеристика главным героям старику и его сыну, в которой особо отмечается их прилежный образ жизни и беднота, что выражено словами фақир, бечорахол. "Бу чол денгиз буйида ёлғиз ўғли билан яшар экан. Улар жуда фақир бўлиб бечорахуол кун кўрар эканлар"[9;ст.1].

В переведённом отрывке особое значение выражают слова "Факир" и "бечорахол". Лингвокультурема "фақир"- имеет значение послушный, безобидный, прилежный человек. Также может использоваться и в значении бедный [2]. Второе слово "бечорахол" означает бедное состояние, то есть, еле сводящий кониы с кониами. В переводе упущено слово "фақир" и речь идёт только о бедности старика и его сына. "Once upon a time, long, long ago, an old fisherman and his only son lived by the side of the sea. They were very poor" [6;ст.4].

Для узбекского народа слово "фақир" имеет чисто национальный характер, другими словами "фақир" - это человек который довольствуется тем, что дал бог и не жалуется на свою бедность, не гоняется за богатством, не обвиняет никого за свою бедность (судьбу). Думаем, что причиной упущения в английском варианте этого значения слова является то, что англоязычные народы при выражении бедности не используют смиренность нуждающихся живущих в нишете. Видимо, по этому английское слово "poor" может заменить две единицы узбекских лингвокультурем "фақир" и "бечорахол".

Здесь уместно отметить, что в английском языке имеются три слова- humble, submissive, meek, которые содержать близкое значение к слову "фақир". Humble - not proud; not thinking of yourself as better than other people (Her success has humbled her critics). Submissive - willing to obey someone else (It's not in her nature to be submissive). Meek - having or showing a quiet and gentle nature; not wanting to fight or argue with other people (A meek child dominated by his brothers), (She may seem meek and mild but it is all an act) [8]. Общее в этих словах довольствоваться тем, что имеют и не жалуются на жизнь.

C учётом утверждённых требований к научным статьям мы не имеем возможности описать до мельчайших подробности всех исследуемых лингвокультурем. Несмотря на это попробуем, расширит границы значений узбекской лингвокультуремы "фақир". В произведениях великого узбекского поэта Алишера Навои находим единицы языка используемые в следующих значениях[1;ст.13].

1.бедний, неимуший (Мавлоно Мажнуний Балхда бўлур, фақир кишидур, китобатқина қила олурки, важхи маош хосил бўлғай) - Мавлоно Мажнуний является факиром и довольствуется тем, что имеет;

2. дервиш (человек который отрёкся от обычной материальной жизни и посветил себя целиком паломничеству, бродячему образу жизни, для которого важно не материальное состояние, а духовное);

3. камина, то есть я. Термин камина является носителем значения "фақир", характеризующий того или иного человека как бедного, но духовно богатого (Мавлоно Шох Али - фақирнинг мадрасасида тахсил қилур) - Мавлоно Шох Али обучается в медресе факира. Здесь уместно констатировать тот факт что слово факир используется и в английской лексике (fakir Moslem holy beggar) [8.ст-57].

Знаменитый поэт Абдурахман Жоми делит лингвокультурему "факир" на два вида: Официальное и истинно - настоящее.

1. Официальное. Это люди неимущие, которые не стремятся иметь богатое состояние и довольствуются бедным образом жизни.

2. Истинно - настоящее. Это люди, которые имея большое, огромное материальное состояние ведут обычную, ничем не отличающуюся от бедного образа жизни.

В узбекском языке имеется слово "зора" которое содержит кроме прямого и переносное значение не уверенности [3; ст.160]. см. (Мен бориб бу ходисани Хонга маълум қилай. Зора мора хон бизга каттароқ инъом берса дебдида шахарга жўнаб кетибди)[9;ст.1]. Здесь лингвокультурема зора -мора имеет значение не уверенности в том, что Хан наградит его чем ни будь за золотую рыбу (Зора-мора=зора). Данное предложение в английском языке выглядит так: 


\begin{tabular}{|c|c|c|c|c|c|c|}
\hline \multirow{4}{*}{ Impact Factor: } & ISRA (India) & $=3.117$ & SIS (USA) & $=0.912$ & ICV (Poland) & $=6.630$ \\
\hline & ISI (Dubai, UAE & $=0.829$ & РИНЦ (Russia) & $=0.156$ & PIF (India) & $=1.940$ \\
\hline & GIF (Australia) & $=0.564$ & ESJI (KZ) & $=\mathbf{5 . 0 1 5}$ & IBI (India) & $=4.260$ \\
\hline & JIF & $=1.500$ & SJIF (Morocco) & $=5.667$ & & \\
\hline
\end{tabular}

"The khan may give us a fine reward for it" [6;ст.3]. Отличие этих двух лингвокультурем в том, что "зора-мора" больше имеет значение не только не уверенности, а уверенности в том, что ничего не получит (точно ничего не получит).

В интерпретации узбекских лингвокультурем на английский язык, определённую трудность вызывают слова, которые выражают неописанное внутренние состояние, то есть, психическое состояние людей. В тексте узбекской народной сказки "Золотая рыба" в одном простом предложении использованы две лингвокультуремы, которые выражают то, или иное состояние человека. См. (бояқ̧ии чол эса денгиз қирғоғида вой болам деб йиғлаганича қолаверибди) - "Meanwhile, the poor old fisherman stood at the water's edge, watching the waves carry his only son farther and farther out to sea" [6;ст.8]. В английском тексте сказки исползовано слово бедний старий рыбак (the poor old fisherman) то есть такое состояние старика, которое вызывает сочувствие, что считается оригинальным переводом. Но вторая лингвокультурема "вой болам" не нашла своё отражение в тексте перевода. Вой болам это сочетание исползуемое в основном при утрате, смерти близкого человека (вой отам, вой онам, вой жигарим....). В этом сочетании вой не является сомостоятелним словом; оно в прямом значении означает крик человека при боли подобно русскому (ай рука болит, ай не бей....) подобно английскому (ouch, aw, AJ, Oh no!) при этом в английском языке используется несколько вариантов единиц, последнее из которых можно считать эквивалентным к слову вой узбекского языка. Несмотря на это, автор перевода не считал нужным выражать внутреннее, психическое состояние старика данными средствами.

Сказка "Золотая рыба" содержит и ряд историко - релегиозных лингвокультурем одним из которых является слово гарем хқарам-harem. Несмотря на то, что эти единицы функционируют в обоих языках, в английском переводе текста лингвокультурема garem не отражена. С первого взгляда слово гарем не имеет важного значения в интерпретации сказки. Но, если вникнут в историю фольклора, мы узнаём, что, сказка тем и дорога нам, что содержит богатую информацию об истории нашей цивилизации. Поэтому здесь уместно было бы использовать имеющееся в английском языке слово harem, которое имеет следующее значение. "Harem - a house or part of a house in which the women of a Muslim household live"[7]. Из выше сказанного понятно, что для девушек и женщин были выделены отдельные комнаты дома для жилья, что являлась цветим местом, куда был запрещен вход мужчинам.
Основная тема и идея любого поэтического и прозаического произведения, в том числе и сказки, формируют её композиционное строение, в который входит сюжет и образы. Узбекская народная сказка "Золотая рыба" тоже состоит из выше сказанных, сюжетную линию которых составляют образы: старого рыбака, его сына (молодого рыбака), золотой рыбы, хана, принцессы и других персонажей. Раскрытие образов происходит действиями, поступками оных. Учитывая важность эту особенность художественных произведении считаем, что в переводе они должны иметь своё отражение так как каждый из этих образов выражает те или иные национальные ценности народа. В анализируемой нами интерпретации сказки "Золотая рыба" замечаем, что часть текста сказки выражающая одну немаловажную линию сюжета вообще не нашло своё отражение. В упущенной части текста речь идёт о хане и его дочери, о раскрытие их образа. Краткое содержание упущенного состоит из следующего: Попрощавшись с рыбой молодой рыбак идёт к хану, чтобы получит обещанную награду, но хан отказывается от своих обещаний и выгоняет молодого рыбака восвояси. Молодой рыбак устраивается на работу в один из уголков города помощником кузнеца. Далее речь идет о дочери хана, которая узнав, что отец прогнал её спасителя, требует справедливости. В случае отказа грозит покончить собою, только тогда хан меняет свое решение и соглашается выдать дочку за молодого рыбака.

Основной темой данного отрывка является взаимоотношения богатых и бедных, чиновников и служащих. Данная тема является ведущей во многих сказках мира. (Это воплощение мечты бедных, неимущих, честных, справедливых, добрых людей). В тексте перевода сказки перед читателем хан представляется справедливым, честным, который держит слово. Но в оригинале он ненавидеть бедных и считает их себе неравными, но соглашается на брак дочери только по её наставлению. Предлагаем краткий вариант упущенного текста: The fisherman came to the palace and asked for reception. But khan did not fulfill his promise to give his daughter for him, and did not let him into the palace. Having lost all hope, with a pain in his heart, the fisherman left the palace and settled himself as an apprentice to the blacksmith on the outskirts of the city. After a week, knowing about the incident, the Khan's daughter lost her peace and with tears in her eyes turned to her father: "If you do not let me to marry to a fisherman who has cured and saved my life, then today you will lose your daughter". - After saying she was going to jump into the river which passed through the harem. But this time the maids 


\begin{tabular}{|c|c|c|c|c|c|c|}
\hline \multirow{4}{*}{ Impact Factor: } & ISRA (India) & $=3.117$ & SIS (USA) & $=0.912$ & ICV (Poland) & $=6.630$ \\
\hline & ISI (Dubai, UAI & $=0.829$ & РИНЦ (Russia) & $=0.156$ & PIF (India) & $=1.940$ \\
\hline & GIF (Australia) & $=0.564$ & ESJI (KZ) & $=5.015$ & IBI (India) & $=4.260$ \\
\hline & JIF & $=1.500$ & SJIF (Morocco) & $=5.667$ & & \\
\hline
\end{tabular}

had managed to retain her. In order not to lose her daughter, khan had to let them to marry.

Характеризуя творческих людей, иследователей, поэтов и писателей в том числе и переводчиков знаменитий английский этнограф Эдуард Бернетт Тайлор (в мелитерации Тэйлор) писал - The philosopher may be so intent upon his general laws of society as to neglect the individual actors of whom that society is made up, and of him it may be said that he cannot see the trees for the forest [4; ст.27] (Философ может придавать так много значения обшим законам социалного бытия, что он совершенно теряет из выда отделных деятелей, из которых состоит общество, и о нем можно сказать, что он за лесом не выдит деревев) [5; ст.26]. Другими словами мы не замечаем деревья, которые составляют лес, точно также переводчик не заметила или считала ненужным поступки хана и дочери, которые также являются главными действующими лицами сказки. Другими словами,они также являются насителями культуры востока, так как вся культурная ценность узбекского народа состоит из личностей носителей его языка. В переносном значении герои этой сказки, это деревья, из которых образуется лес.

\section{Conclusion}

В завершении хотелось бы отметить, что языковые явления, единицы языка, в том числе, лингвокультуремы, их прямые, переносные и внутренние значения (отражающие культурные ценности народа) являются открытыми. Этот принцип изучения сущности языка даёт возможность исследователю в широком ракурсе анализировать многозначные выражения и фразы разно - системных языков мира. При этом считается необходимым учёт особенностей каждого языка без которого любая интерпретация переводимого текста теряет национальность, подобно массовой культуре. Интерпретируя сказанное можно обобщить: не надо забывать "деревья", которые составляют "лес".

\section{References:}

1. Isakova, Z. M. (2010). Alisher Navoijning «MAZhOLIS UN-NAFOIS» asaridagi izhtimoij - sijosij leksika. 10.02.01 - uzbek tili. Filologija fanlari nomzodi ilmij darazhasini olish uchun taқdim jetilgan dissertacija avtoreferati. Toshkent.

2. (1959). Uzbeksko-russkij slovar'. In: S.F. Akabirova, Z.M. Magrufova, A.T. Hodzhahanova (Eds.). Moskva: Gosudarstvennoe izdatel'stvo inostrannyh i nacional'nyh slovarej.

3. Madvaliev, A. (2006). Uzbek tilining izox̦li luzati. V zhildli, tax̧riri ostida. T.: ЎzMJe, 2006-2008.
4. Tylor, E. B. (1920). Primitive Culture. (p.520). London. John Murray, Albemarle street,w.

5. Tajlor, J. B. (1989). Pervobytnaja kul'tura: Per.s ang. (p.573). M.: Politizdat.

6. (1983) The Golden Fish. An Uzbek Fairy Tale. Translated by Fainna Solasko. (p.3). Moscow: Malish Publishers.

7. (n.d). Merriam - Webster Dictionary.

8. (1977) Webster's New world dictionary / Simon and Schuster (p.57). USA.: William Collins publishers.

9. (n.d.). Retrieved 2018, from http://www.macmillandictionary.com/fakir

10. (n.d.). Oltin baliķ. Retrieved 2018, from http://www.Ziyonet.uz 